\title{
Preservation of pleural integrity during coronary artery bypass surgery affects respiratory functions and postoperative pain: A prospective study
}

\author{
Bilgehan Savas Oz MD¹, Hikmet lyem MD¹, Hakki Tankut Akay MD¹, Vedat Yildirim MD², Kubilay Karabacak MD, \\ Cengiz Bolcal MD ${ }^{1}$, Ufuk Demirkiliç $M D^{1}$, Harun Tatar $M D^{1}$
}

BS Oz, H Iyem, HT Akay, et al. Preservation of pleural integrity during coronary artery bypass surgery affects respiratory functions and postoperative pain: A prospective study. Can Respir J 2006;13(3):145-149.

OBJECTIVE: To evaluate the role of preserved pleural integrity in postoperative pain and respiratory functional status in patients undergoing coronary revascularization.

METHODS: Two hundred forty patients undergoing on-pump coronary artery bypass grafting between March 2004 and February 2005 were included in the present study. The patients were prospectively randomized and divided into either an opened pleura (OP) group $(n=120$, patients with an OP) or a closed pleura (CP) group ( $n=120$, patients whose pleural integrity was preserved). Preoperative patient characteristics were similar. Postoperative respiratory functions were compared between the groups by chest $\mathrm{x}$-rays, respiratory functional tests and arterial blood gas analyses. Postoperative pain was compared by using a multidimensional pain score. All the tests were examined by the same blinded clinician.

RESULTS: The mean age of the patients was $60.4 \pm 8.8$ years. Postoperative bleeding and the duration of hospital stay were markedly higher in the OP group than in the CP group. The incidences of atelectasis and pleural effusion were also significantly higher in the OP group $(\mathrm{P}<0.01)$. Respiratory functions and postoperative pain scores were better in the $C P$ group $(\mathrm{P}<0.01$ and $\mathrm{P}=0.008$, respectively).

CONCLUSIONS: Preserving pleural integrity has beneficial effects on the respiratory functions and postoperative pain after coronary revascularization. The preservation of pleural integrity results in better respiratory function, decreased hospital stay and cost, and as a consequence, a better surgical outcome.

Key Words: Atelectasis; Coronary bypass; Pleural effusion; Pleural integrity; Postoperative pain; Respiratory functions
Incidence du maintien de l'intégrité de la plèvre sur le fonctionnement respiratoire et la douleur postopératoire dans les pontages coronariens : étude prospective

OBJECTIF : L'étude visait à évaluer l'incidence du maintien de l'intégrité de la plèvre sur la douleur postopératoire et le fonctionnement respiratoire chez des patients ayant subi une intervention de revascularisation coronarienne.

MÉTHODE : Deux cent quarante patients ayant subi un pontage coronarien sous circulation extracorporelle entre mars 2004 et février 2005 ont participé à l'étude. Les sujets ont été dirigés au hasard et de façon prospective vers le groupe de la plèvre ouverte $(\mathrm{PO} ; \mathrm{n}=120)$ ou vers le groupe de la plèvre fermée (PF; $\mathrm{n}=120$; maintien de l'intégrité de la plèvre). Avant l'opération, les caractéristiques des patients étaient à peu près les mêmes. Après l'opération, nous avons comparé le fonctionnement respiratoire entre les deux groupes à partir de radiographies pulmonaires, d'examens fonctionnels respiratoires et d'analyses des gaz sanguins artériels. Pour ce qui est de la douleur postopératoire, nous avons utilisé une échelle d'évaluation pluridimensionnelle. Les examens ont tous été soumis au même clinicien, tenu dans l'ignorance des sujets.

RÉSULTATS : L'âge moyen des patients était de 54,4 $\pm 8,8$ ans. La fréquence des hémorragies postopératoires était beaucoup plus élevée et la durée du séjour, beaucoup plus longue dans le groupe de la $\mathrm{PO}$ que dans le groupe de la PF. De plus, l'incidence de l'atélectasie et des épanchements pleuraux était significativement plus élevée dans le groupe de la $\mathrm{PO}$ que dans l'autre groupe $(\mathrm{P}<0,01)$. En contrepartie, les résultats des examens fonctionnels respiratoires et de l'évaluation de la douleur postopératoire étaient meilleurs dans le groupe de la $\mathrm{PF}(\mathrm{P}<0,01$ et $\mathrm{P}=0,008$ respectivement).

CONCLUSIONS : Le maintien de l'intégrité de la plèvre a eu des effets favorables sur le fonctionnement respiratoire et la douleur postopératoire après une intervention de revascularisation coronarienne. Le maintien de l'intégrité de la plèvre s'est soldé par un meilleur fonctionnement respiratoire, une diminution du séjour à l'hôpital, une réduction des coûts et, par le fait même, de meilleurs résultats de la chirurgie. lthough there are many alternatives, the left internal mam-
marian artery (IMA) is widely used as a conduit of choice
for myocardial revascularization. It has superior graft patency
and increased long-term survival compared with saphenous
vein bypass grafting (1). Many studies, as well as the clinical
experience of cardiovascular surgeons, have shown that respi-
ratory problems are one of the major factors affecting morbidity
and mortality after coronary artery bypass grafting (CABG).
Anesthesia-related problems, poor pulmonary function, car-
diopulmonary bypass (CPB) and operative techniques are the
most widely known reasons for respiratory complications after
CABG. Some studies indicate that among patients undergoing $\mathrm{CABG}$, marked impairment in pulmonary function is more pronounced in those receiving IMA grafts. Pleurotomy during IMA harvesting may also affect respiratory function during the postoperative period (2,3). Matsumoto et al (4) suggested that the preparation of a wide IMA pedicle with surrounding tissue and parts of the endothoracic fascia has more influence on blood loss and postoperative pain, whereas a closed pleural cavity has a greater positive effect on postoperative respiratory functions. Impaired pleural integrity, traction of the sternum and damage to the thorax wall during IMA harvesting may be

${ }^{1}$ Department of Cardiovascular Surgery; ${ }^{2}$ Department of Anesthesia and Reanimation, Gulhane Military Medical Academy, Ankara, Turkey Correspondence: Dr Hakki Tankut Akay, PK 56, 06552, Çankaya, Ankara, Turkey. E-mail tankutakay@gmail.com 


\begin{tabular}{lll}
\multicolumn{2}{l}{ TABLE 1 } \\
Postoperative pain score
\end{tabular}

the causative factors. Many studies have shown that pleural effusion, atelectasis, blood loss, the need for a secondary thoracotomy, pain and intercostal neuralgia are less in patients not receiving an IMA graft (5-8). Yet, the effects of pleural integrity on respiratory functions are not completely clear.

The present prospective, randomized study examined the effects of pleural integrity (in patients with a closed pleura [CP] during CABG versus patients who received IMA harvested with an opened pleura [OP]) on postoperative pulmonary functions and pain.

\section{METHODS}

After the approval of the local ethics committee at the authors' institution, a detailed written informed consent was obtained from all patients. Two hundred forty patients undergoing on-pump CABG between March 2004 and February 2005 were included in the prospective study. Patients were randomly assigned into two groups. In the $\mathrm{CP}$ group, pleural integrity was preserved in patients during $\mathrm{CABG}$, whereas, in the OP group, the pleura was opened during the harvesting of IMA. Random assignment to the OP group or the CP group was performed on the day of operation. When the pleura was opened coincidentally, the opening was widened and that patient was included in the OP group (11 patients).

The effects of pleurotomy on respiratory complications were observed; therefore, any concomitant disease that could affect the results was excluded. In this respect, patients with chronic obstructive pulmonary disease (COPD), skeletal abnormalities that cause pulmonary restriction and those older than 70 years of age were not enrolled in the study. The diagnosis of COPD was made by respiratory function tests performed by the Department of Pulmonology at the authors' institution. Routinely, the mediastinal and chest tubes were removed on the first postoperative day. On the second postoperative day, central and arterial lines and the urinary catheter were removed, and the patients were mobilized. A delay in the removal of tubes was another exclusion criterion. Early reoperations were not excluded if there was no delay in the removal of chest tubes. Reoperation for bleeding was defined as bleeding that required early surgical re-exploration after initial departure from the operating room. The criteria were as follows: the drainage of more than $500 \mathrm{~mL}$ of blood during the first $1 \mathrm{~h}$, more than $400 \mathrm{~mL}$ during each of the first $2 \mathrm{~h}$, more than $300 \mathrm{~mL}$ during each of the first $3 \mathrm{~h}$ or more than $1000 \mathrm{~mL}$ in total in the first $4 \mathrm{~h}$; sudden massive bleeding; obvious signs of cardiac tamponade; and excess bleeding despite correction of coagulopathies. IMA harvesting was performed by the same surgical team with the same technique, but in some patients, pleural integrity was preserved (extrapleural harvesting, $n=120$ ) and, in the remaining patients, the pleura was opened (harvesting with pleurotomy, $\mathrm{n}=120$ ). The number of anastomoses was similar between the $\mathrm{OP}$ group and the $\mathrm{CP}$ group.
The following parameters were compared between groups: vital capacity (VC), forced expiratory volume in $1 \mathrm{~s}\left(\mathrm{FEV}_{1}\right)$ and $\mathrm{FEV}_{1} / \mathrm{VC} \%$. At each examination, arterial blood gas analysis (partial pressure of oxygen, partial pressure of carbon dioxide and oxygen saturation) was performed.

Chest $\mathrm{x}$-rays were evaluated routinely one day before the operation, and five and 30 days after the operation for pleural effusion and atelectasis.

All patients received the same postoperative analgesic therapy, which consisted of oral nonsteroid analgesics administered during the first six postoperative days (paracetamol, $3 \times 1000 \mathrm{mg}$ ). Localization of pain was classified as sternal and shoulder pain or suspenders pain. The latter was defined as bilateral parasternal pain being expressed over more than one-half the height of the thorax. Postoperative pain quality and intensity were evaluated by using a multidimensional pain score (9). Pain quality was divided into a subscale of seven topics, each consisting of three adjectives, for which patients had to assign a numerical score (one to four points; Table 1).

Pleural effusion was considered relevant when exceeding the phrenocostal angle, and atelectasis was recorded when showing a clear radiological shadow of more than $15 \mathrm{~mm}$. Roentgenograms were examined by the same blinded radiologist. Linear atelectasis was not recorded. Cases with mediastinal drainage of any kind and sternal dehiscence were recorded. Patients with a positive serological culture of the mediastinal drainage and sternal dehiscence were accepted as having mediastinitis, and appropriate medication was given. A second look due to postoperative bleeding and mediastinitis was recorded as reoperation. Daily $\mathrm{x}$-rays were examined for evaluating phrenic nerve injury. Thoracic ultrasonography was performed on the third postoperative day for the same aim.

\section{Operation technique}

The routine CABG protocol of the authors' cardiovascular surgery clinic was applied to all patients. Anesthesia was induced with $20 \mu \mathrm{g} / \mathrm{kg}$ fentanyl citrate, $0.12 \mathrm{mg} / \mathrm{kg}$ pancuronium and $2 \mathrm{mg} / \mathrm{kg}$ propofol. After tracheal intubation, mechanical ventilation was instituted with a $6 \mathrm{~mL} / \mathrm{kg}$ to $8 \mathrm{~mL} / \mathrm{kg}$ tidal volume and a 10 breaths $/ \mathrm{min}$ to 12 breaths/min respiratory rate. Anesthesia was maintained with $10 \mu \mathrm{g} / \mathrm{kg}$ fentanyl and $1 \mathrm{mg} / \mathrm{kg}$ propofol administered as an infusion. Two milligrams of pancuronium were given every $45 \mathrm{~min}$ throughout the operation. Aortic and two-stage venous cannulae were used to institute the CPB using a roller pump, membrane oxygenation and identical priming solution. Systemic blood flow was maintained at $2.2 \mathrm{~L} / \mathrm{m}^{2}$ to $2.4 \mathrm{~L} / \mathrm{m}^{2}$ and mean arterial blood pressure was maintained at $60 \mathrm{mmHg}$ to $70 \mathrm{mmHg}$ during CPB. Systemic hypothermia $\left(28^{\circ} \mathrm{C}\right)$ and hemodilution were applied. Distal anastomoses were performed during the cross-clamp period. Proximal anastomoses were performed with a partial occluding clamp in the beating heart. All the left anterior descending arteries received a pediculated left IMA flap. The other vessels received greater saphenous vein grafts (SVGs). Postoperative pharmacological support was instituted according to hemodynamic requirements.

In all patients, IMA harvesting was performed using conventional technique (with pedicule); it was harvested with endothoracic fascia and the just-surrounding fat and muscle tissue accompanied with its vein. If the flow of the IMA was adequate, it was kept in a papaverinized surgical sponge and anastomosed to the left anterior descending artery. In all patients, pericardial (28 Fr) and mediastinal $(32 \mathrm{Fr}$ ) chest tubes were inserted. In the $\mathrm{OP}$ group, additional left hemithorax (32 Fr) tubes were also placed for drainage; these tubes were removed routinely on the first postoperative day, upon a change in the drainage toward serosity. 
TABLE 2

Preoperative demographic data of the patients

\begin{tabular}{lcccc}
\hline & Total & OP group & CP group & P \\
\hline Patients $(\mathrm{n})$ & 240 & 120 & 120 & \\
Age (mean years $\pm \mathrm{SD})$ & $60.4 \pm 8.8$ & $59.2 \pm 6.6$ & $61.5 \pm 7.1$ & $\mathrm{NS}$ \\
Men & 169 & 86 & 83 & $\mathrm{NS}$ \\
Women & 71 & 34 & 37 & $\mathrm{NS}$ \\
Ejection fraction $(\%)$ & $58.3 \pm 4.4$ & $59.1 \pm 3.2$ & $57.4 \pm 2.5$ & $\mathrm{NS}$ \\
Body mass index $\left(\mathrm{kg} / \mathrm{m}^{2}\right)$ & $23.3 \pm 1.0$ & $24.1 \pm 0.9$ & $23.1 \pm 0.3$ & $\mathrm{NS}$ \\
Hematocrit $(\%)$ & $44.3 \pm 4.5$ & $43.6 \pm 3.5$ & $45.3 \pm 3.6$ & $\mathrm{NS}$ \\
\hline
\end{tabular}

CP Closed pleura (group with preserved pleural integrity); OP Opened pleura (group with OP harvesting); NS Not significant

\section{Statistical analysis}

Statistical analysis was performed with SPSS software (version 10.0, SPSS Inc, USA). Clinical data were expressed as means \pm SDs and percentages. Differences between groups were investigated by the Levene test, the independent samples $t$ test and the $\chi^{2}$ test. The effects of variables were investigated by calculating odds ratios in univariate analyses for all patients. Differences were considered significant at $\mathrm{P}<0.05$.

\section{RESULTS}

Of the 240 patients, 169 were men. The mean age of the patients was $60.4 \pm 8.8$ years. The preoperative demographic data of the patients are shown in Table 2. The demographic and clinical data of the patients in both the OP group and the CP group were similar. Intraoperative and postoperative characteristics of the patients are summarized in Table 3. Postoperative bleeding $(\mathrm{P}<0.01)$ and hospital stay $(\mathrm{P}=0.046)$ were higher in the OP group than in the CP group. Myocardial performance and hemodynamic status were found to be optimum in both groups, as measured by electrocardiography, echocardiography and cardiac enzyme levels. No cardiac ischemic event was observed in the hospital or short-term follow-up period.

Radiological assessment

On the fifth and 30th postoperative days, atelectasis and pleural effusion were compared between the groups. The incidences of atelectasis and pleural effusion were significantly higher in the OP group than in the CP group (Table 4). Daily x-rays and an ultrasound on the third postoperative day revealed no evidence of phrenic nerve injury.

\section{Pulmonary function}

The patients were extubated after a mean of $14.49 \pm 10.22 \mathrm{~h}$. Mechanical ventilation times were similar in both groups. Pulmonary function tests are compared in Table 5. The FEV showed a significant decrease five days postoperatively in the OP group (OP group: $61.2 \% \pm 3.6 \%$; CP group: $76.1 \% \pm 6.2 \%$; $\mathrm{P}<0.001)$. VC was significantly more restricted in the OP group at 30 days postoperatively (OP group: $85.3 \% \pm 4.2 \%$; $\mathrm{CP}$ group: $96.2 \% \pm 5.4 \% ; \mathrm{P}<0.001$ ). Arterial blood gas analysis of both groups is summarized in Table 6 . On the fifth postoperative day, partial pressure of oxygen and oxygen saturation were significantly higher and the partial pressure of carbon dioxide was significantly lower in the CP group.

\section{Postoperative pain}

On the fifth postoperative day, the incidence of sternal pain was $36.8 \%$ and $9.1 \%$ in the OP group and the CP group,
TABLE 3

Intraoperative and postoperative characteristics of the patients

\begin{tabular}{lcccc}
\hline & Total & OP group & CP group & P \\
\hline CC time (min) & $51.25 \pm 20.91$ & $53.93 \pm 21.66$ & $50.57 \pm 15.31$ & 0.695 \\
CPB time (min) & $81.89 \pm 34.79$ & $82.94 \pm 34.82$ & $78.63 \pm 31.27$ & 0.715 \\
Ventilation time (h) & $14.49 \pm 10.22$ & $14.56 \pm 11.45$ & $15.36 \pm 8.81$ & 0.823 \\
Bleeding (mL) & $639.80 \pm 368.34$ & $680.13 \pm 39.25$ & $608.43 \pm 232.71<0.001$ \\
Reoperation (n) & 7 & 4 & 3 & 0.52 \\
Mortality (n) & 3 & 2 & 1 & 0.51 \\
Hospital stay (days) & $8.2 \pm 2.3$ & $8.8 \pm 2.1$ & $7.1 \pm 1.9$ & 0.046
\end{tabular}

CC Cross clamp; CP Closed pleura (group with preserved pleural integrity); CPB Cardiopulmonary bypass; OP Opened pleura (group with OP harvesting)

TABLE 4

Postoperative atelectasis and pleural effusion

\begin{tabular}{|c|c|c|c|c|}
\hline & \multicolumn{2}{|c|}{ Atelectasis, n (\%) } & \multicolumn{2}{|c|}{ Pleural effusion, $\mathbf{n}(\%)$} \\
\hline & Present & Absent & Present & Absent \\
\hline \multicolumn{5}{|c|}{5 days postoperatively } \\
\hline OP group & $52(43)$ & $68(57)$ & $38(31)$ & $82(69)$ \\
\hline CP group & $28(23)$ & $92(77)$ & $14(12)$ & $106(88)$ \\
\hline $\mathrm{P}$ & & $<0.001$ & & $<0.001$ \\
\hline \multicolumn{5}{|c|}{30 days postoperatively } \\
\hline OP group & $12(10)$ & $108(90)$ & $14(12)$ & $106(88)$ \\
\hline CP group & $2(1.6)$ & $118(98.4)$ & $3(2.5)$ & $117(97.5)$ \\
\hline $\mathrm{P}$ & & 0.002 & & 0.001 \\
\hline
\end{tabular}

$\mathrm{CP}$ Closed pleura (group with preserved pleural integrity); OP Opened pleura (group with OP harvesting)

respectively $(\mathrm{P}=0.001)$. Shoulder pain was not markedly different during follow-up examination. The incidence of suspenders pain was found to be $33.3 \%$ in the OP group and $7.3 \%$ in the $\mathrm{CP}$ group $(\mathrm{P}=0.001)$. The multidimensional pain score was used to evaluate pain quality. Patients suffering from sharper (stabbing) pain were more common in the OP group at five days (OP group: $6.3 \pm 0.5$; $\mathrm{CP}$ group: $3.2 \pm 0.3 ; \mathrm{P}=0.016$ ) and 30 days after surgery (OP group: $3.2 \pm 0.2$; CP group: 1.6 \pm 0.1 ; $\mathrm{P}=0.032$ ). More annoying (troublesome) pain was also more common in the OP group at five days (OP group: $7.2 \pm 0.3$; CP group: $2.5 \pm 0.2 ; \mathrm{P}=0.036$ ) and 30 days after surgery (OP group: $6.4 \pm 0.5$; CP group: $2.1 \pm 0.3 ; \mathrm{P}=0.040$ ). Sudden pain was expressed significantly less in the $\mathrm{CP}$ group 30 days postoperatively (OP group: 4.2 \pm 0.3 ; $\mathrm{CP}$ group: $1.2 \pm 0.3 ; \mathrm{P}=0.008$ ). Rhythmical, persistent, electrifying and thermal pain were not significantly different between groups.

Seven patients were reoperated on in the first $24 \mathrm{~h}$ due to postoperative bleeding (five in the OP group and two in the CP group). Overall mortality was $1.25 \%$. Two patients in the $\mathrm{OP}$ group died due to prolonged mechanical ventilation resulting in serious lung infections. One patient in the CP group died due to ventricular fibrillation.

\section{DISCUSSION}

It is well known that IMA is the ideal graft for revascularization (10). The preservation of pleural integrity is controversial. Some surgeons believe that with preserved pleural integrity, there can be tension and/or torsion on IMA, and the inflated lung can dislocate IMA, which may cause injury, especially in the case of CABG reoperations (11). An alternative is the separation of the fatty tissue between the pleura and mediastinum 
TABLE 5

Comparison of preoperative and postoperative pulmonary function

\begin{tabular}{|c|c|c|c|c|c|c|c|c|c|}
\hline & \multicolumn{3}{|c|}{ Before operation } & \multicolumn{3}{|c|}{5 days postoperatively } & \multicolumn{3}{|c|}{30 days postoperatively } \\
\hline & OP group & CP group & $\mathbf{P}$ & OP group & CP group & $\mathbf{P}$ & OP group & CP group & $\mathbf{P}$ \\
\hline $\mathrm{FEV}_{1}(\%)$ & $80.3 \pm 7.9$ & $82.1 \pm 6.4$ & 0.823 & $61.2 \pm 3.6$ & $76.1 \pm 6.2$ & 0.001 & $71.4 \pm 5.9$ & $80.3 \pm 3.4$ & 0.032 \\
\hline VC (\%) & $98.1 \pm 6.2$ & $96.3 \pm 1.4$ & 0.798 & $71.9 \pm 5.3$ & $89.5 \pm 3.4$ & $<0.001$ & $85.3 \pm 4.2$ & $96.2 \pm 5.4$ & 0.029 \\
\hline $\mathrm{FEV}_{1} / \mathrm{VC}$ & $97.2 \pm 11.7$ & $99.2 \pm 12.2$ & 0.811 & $69.4 \pm 15.1$ & $88.1 \pm 14.3$ & $<0.001$ & $81.5 \pm 11.2$ & $95.2 \pm 12.1$ & $<0.001$ \\
\hline
\end{tabular}

CP Closed pleura (group with preserved pleural integrity); FEV 1 Forced expiratory volume in 1 s; OP Opened pleura (group with OP harvesting); VC Vital capacity

\begin{tabular}{|c|c|c|c|}
\hline & OP group & CP group & $\mathbf{P}$ \\
\hline Preoperative $\mathrm{PaO}_{2}(\mathrm{mmHg})$ & $79.1 \pm 3.2$ & $77.9 \pm 2.7$ & 0.782 \\
\hline Postoperative $\mathrm{PaO}_{2}(\mathrm{mmHg})$ & $64.1 \pm 9.4$ & $75.7 \pm 8.3$ & 0.031 \\
\hline$P$ & $<0.001$ & 0.832 & \\
\hline Preoperative $\mathrm{PaCO}_{2}(\mathrm{mmHg})$ & $32.1 \pm 3.4$ & $31.3 \pm 4.2$ & 0.841 \\
\hline Postoperative $\mathrm{PaCO}_{2}(\mathrm{mmHg})$ & $37.3 \pm 3.4$ & $33.4 \pm 6.7$ & 0.043 \\
\hline$P$ & 0.037 & 0.698 & \\
\hline Preoperative $\mathrm{O}_{2}$ saturation (\%) & $99.1 \pm 1.3$ & $99.2 \pm 1.7$ & 0.912 \\
\hline Postoperative $\mathrm{O}_{2}$ saturation (\%) & $95.1 \pm 1.1$ & $98.5 \pm 1.8$ & 0.038 \\
\hline$P$ & 0.044 & 0.774 & \\
\hline
\end{tabular}

CP Closed pleura (group with preserved pleural integrity); OP Opened pleura (group with OP harvesting); $\mathrm{PaCO}_{2}$ Partial pressure of carbon dioxide; $\mathrm{PaO}_{2}$ Partial pressure of oxygen

and/or the fasciotomy to the IMA pedicle (12). We hypothesized that preserved pleural integrity could prevent lung injury and the exposure of the thorax to blood during the operation, which would thus decrease the incidence of pleural effusion, atelectasis, pain and prolonged bleeding in the postoperative period. In our series, IMA was located in a groove formed by the thymus and the fatty tissue. In some cases, tension was decreased by fasciotomy to the IMA pedicle.

Noera et al (13) evalauted the postoperative parameters of 433 patients. Atelectasis in the lower lobe, pleural effusion, a decrease in lung volume and bleeding were all less in the $\mathrm{CP}$ group than in the OP group. Sternal wound infection was observed in three patients in the OP group. No sternal infections were observed in the CP group. Totaro et al (14) found that postoperative bleeding was less in patients with preserved pleural integrity, but the duration of mechanical ventilation was not different from that in patients with an OP. In a study of 299 patients, Bonacchi et al (15) reported that bleeding of more than $1000 \mathrm{~mL}$ was seen in $7.5 \%$ of patients with preserved pleural integrity compared with $19 \%$ of patients with an OP $(\mathrm{P}<0.028)$. They reported that the duration of stay in an intensive care unit, unilateral pleural effusion, the need for a thoracentesis procedure and atelectasis were significantly more in patients with an OP. Wimmer-Greinecker et al (16) evaluated 112 patients and found that the incidence of bleeding was higher in patients with an OP. The radiological findings on the sixth postoperative day showed that pleural effusion and atelectasis were more common in patients with an OP. In our study, we also observed that pleural effusion and atelectasis on the fifth and 30th postoperative days were significantly more common in the OP group. Statistical analysis revealed that postoperative bleeding was also significantly higher in the OP group. Vargas et al (17) evaluated 30 patients undergoing $\mathrm{CABG}$ and showed that the incidence of pleural effusion observed by computed tomography was approximately $65 \%$ on both day 2 and day 7 , and most of the pleural effusions were minimal. The incidence of pleural effusion on the right side decreased from $56.7 \%$ (day 2) to $23.3 \%$ (day 7). However, on the left side, the incidence did not change. The factors involved in the persistence of the left effusion included the early removal of the chest tubes and the probable persistence of a pericardial effusion. No differences were observed between patients who received SVG versus IMA grafting. The evaluation of atelectasis showed similar results. A high incidence of atelectasis $(86.7 \%)$, mainly the laminar type, was found on the lower lobes, with no difference between the right lung and left lung or between patients who received SVG versus IMA grafting. The incidence of atelectasis decreased on the right side from $86.7 \%$ (day 2) to $30.0 \%$ (day 7 ), but not on the left side. These postoperative pleuropulmonary changes were caused by thoracic trauma, in particular by the effects of the inflammatory response to the CPB. Lim et al (18) enrolled 206 patients undergoing cardiac surgery; these patients were divided into two groups: one with routine or incidental left pleurotomy and the other with an intact left pleura. Although patients with a left pleurotomy $(n=164)$ had a higher incidence of left lung atelectasis (67.7\% versus $45.2 \% ; \mathrm{P}=0.007)$, neither radiographic consolidation ( $7.5 \%$ versus $7.3 \%$; $\mathrm{P}=0.96$ ) and effusion (42.5\% versus $46.3 \% ; \mathrm{P}=0.66)$ nor hospital stay (nine days in both groups; $\mathrm{P}=0.83$ ) was significantly increased. In our series, we found significant differences in atelectasis, pleural effusion and hospital stay between groups. This finding can be explained by the selection criteria of our study, specifically because patients with COPD and other concomitant repiratory diseases that could affect the respiratory complications were excluded.

Taggart (19) showed that inflammatory reactions affect postoperative pulmonary functions, but it is known that there are several other factors that alter pulmonary functions in the postoperative period. Peng et al (20) showed that $41 \%(n=122)$ of patients with an OP had pleural effusion on the sixth postoperative day. In our series, the respective incidences of pleural effusion in the OP group and the CP group were $31 \%$ and $12 \%$ on the fifth postoperative day, and $12 \%$ and $2.5 \%$ on the 30 th postoperative day. Matsumoto et al (4) showed that pleurotomy does not affect postoperative $\mathrm{FEV}_{1}$. However, in that study, the pulmonary function test was performed 20 to 30 days postoperatively and may not have been influenced by postoperative pain. In our study, $\mathrm{FEV}_{1}$ levels were better in the $\mathrm{CP}$ group on both the fifth and 30th postoperative days. Controversy exists about the effect of pleurotomy on postoperative pulmonary function. Previous data have shown that pleurotomy in patients undergoing $\mathrm{CABG}$ reduces pulmonary function $(2,21)$ because 
of increased incidences of pleural effusion and atelectasis $(20,22)$, increased intrapulmonary shunting (23) and increased postoperative pain due to more extensive surgical trauma to the chest wall (5). Wimmer-Greinecker et al (16) showed that patients with an OP had more pain during the first week of the postoperative period.

In our study, the assessment of postoperative pain quality and intensity was performed by using the multidimensional pain score described by Lehrl et al (9). The subscale and description of pain quality were translated from the German language, and there may be some minor differences compared with the original application.

It has been reported that severe postoperative pain is present in patients undergoing CABG in which IMA is harvested (5). Our results show that the patients who had IMA harvested in standard fashion and whose pleura was opened suffered significantly from stabbing and troublesome pain. These patients also experienced sternal and suspenders pain significantly more often than patients with preserved pleural

\section{REFERENCES}

1. Boylan MJ, Lytle BW, Loop FD, et al. Surgical treatment of isolated left anterior descending coronary stenosis. Comparison of left internal mammary artery and venous autograft at 18 to 20 years of follow-up. J Thorac Cardiovasc Surg 1994;107:657-62.

2. Taggart DP, el-Fiky M, Carter R, Bowman A, Wheatley DJ. Respiratory dysfunction after uncomplicated cardiopulmonary bypass. Ann Thorac Surg 1993;56:1123-8.

3. Royston D, Minty BD, Higenbottam TW, Wallwork J, Jones GJ. The effect of surgery with cardiopulmonary bypass on alveolarcapillary barrier function in human beings. Ann Thorac Surg 1985;40:139-43.

4. Matsumoto M, Konishi Y, Miwa S, Minakata K. Effect of different methods of internal thoracic artery harvest on pulmonary function. Ann Thorac Surg 1997;63:653-5.

5. Cohen AJ, Moore P, Jones C, et al. Effect of internal mammary harvest on postoperative pain and pulmonary function. Ann Thorac Surg 1993;56:1107-9.

6. Shapira N, Zabatino SM, Ahmed S, Murphy DM, Sullivan D, Lemole GM. Determinants of pulmonary function in patients undergoing coronary bypass operations. Ann Thorac Surg 1990;50:268-73.

7. Hurlbut D, Myers ML, Lefcoe M, Goldbach M. Pleuropulmonary morbidity: Internal thoracic artery versus saphenous vein graft. Ann Thorac Surg 1990;50:959-64.

8. Conacher ID, Doig JC, Rivas L, Pridie AK. Intercostal neuralgia associated with internal mammary artery grafting. Anaesthesia 1993;48:1070-1.

9. Lehrl S, Cziske R, Blaha L. Schmerzmessung durch die Mehrdimensionale Schmerzskala MSS. In: Lehrl S, Cziske R, Blaha L, eds. Reihe Medizinpsychologie. Vaterstetten-Munchen: Vless GmbH, 1980:70-5.

10. Spencer FC. The internal mammary artery: The ideal coronary bypass graft? N Engl J Med 1986;314:50-1.

11. Landymore RW, Howell F. Pulmonary complications following myocardial revascularization with the internal mammary artery graft. Eur J Cardiothorac Surg 1990;4:156-62.

12. Cosgrove DM, Loop FD. Techniques to maximize mammary artery length. Ann Thorac Surg 1985;40:78-9. integrity, probably because of chest wall trauma and damage to intercostal nerves.

\section{CONCLUSIONS}

Our study showed that preservation of pleural integrity may decrease the incidence of atelectasis, pleural effusion and pain during the postoperative period. This may be an important factor for patients with an increased risk of postoperative respiratory problems. In patients with chronic pulmonary disease or a concomitant disease that may adversly affect postoperative respiratory functions, preserved pleural integrity may decrease the possibilty of respiratory complications such as atelectasis and pleural effusion, and thus, may help to improve respiratory functions.

We showed that the preservation of pleural integrity during IMA harvesting decreases postoperative bleeding, pleural effusion, atelectasis, pain and hospital stay. We conclude that preservation of pleural integrity, when possible, may decrease the discussed postoperative complications of CABG.

13. Noera G, Pensa PM, Guelfi P, Biagi B, Lodi R, Carbone C. Extrapleural takedown of the internal mammary artery as a pedicle. Ann Thorac Surg 1991;52:1292-4.

14. Totaro P, Fucci C, Minzioni G. Preserved pleura space integrity and respiratory dysfunction after coronary surgery. Eur J Cardiothorac Surg 2001;20:1067-70.

15. Bonacchi M, Prifti E, Giunti G, Salica A, Frati G, Sani G. Respiratory dysfunction after coronary artery bypass grafting employing bilateral internal mammary arteries: The influence of intact pleura. Eur J Cardiothorac Surg 2001;19:827-33.

16. Wimmer-Greinecker G, Yosseef-Hakimi M, Rinne T, et al. Effect of internal thoracic artery preparation on blood loss, lung function, and pain. Ann Thorac Surg 1999;67:1078-82.

17. Vargas FS, Uezumi KK, Janete FB, et al. Acute pleuropulmonary complications detected by computed tomography following myocardial revascularization. Rev Hosp Clin Fac Med Sao Paulo 2002;57:135-42.

18. Lim E, Callaghan C, Motalleb-Zadeh R, et al. A prospective study on clinical outcome following pleurotomy during cardiac surgery. Thorac Cardiovasc Surg 2002;50:287-91.

19. Taggart DP. Respiratory dysfunction after cardiac surgery: Effects of avoiding cardiopulmonary bypass and the use of bilateral internal mammary arteries. Eur J Cardiothorac Surg 2000;18:31-7.

20. Peng MJ, Vargas FS, Cukier A, Terra-Filho M, Teixeira LR, Light RW. Postoperative pleural changes after coronary revascularization. Comparison between saphenous vein and internal mammary artery grafting. Chest 1992;101:327-30.

21. Ferdinande PG, Beets G, Michels A, Lesaffre E, Lauwers P. Pulmonary function tests after different techniques for coronary artery bypass surgery. Saphenous vein versus single versus double internal mammary artery grafts. Intens Care Med 1988;14:623-7.

22. Zin WA, Caldeira MP, Cardoso WV, Auler JO Jr, Saldiva PH. Expiratory mechanics before and after uncomplicated heart surgery. Chest 1989;95:21-8.

23. Burgess GE III, Cooper JR Jr, Marino RJ, Peuler MJ, Mills NL, Ochsner JL. Pulmonary effect of pleurotomy during and after coronary artery bypass with internal mammary artery versus saphenous vein grafts. J Thorac Cardiovasc Surg 1978;76:230-4. 


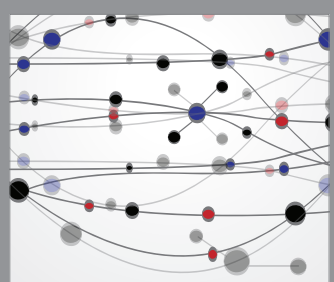

The Scientific World Journal
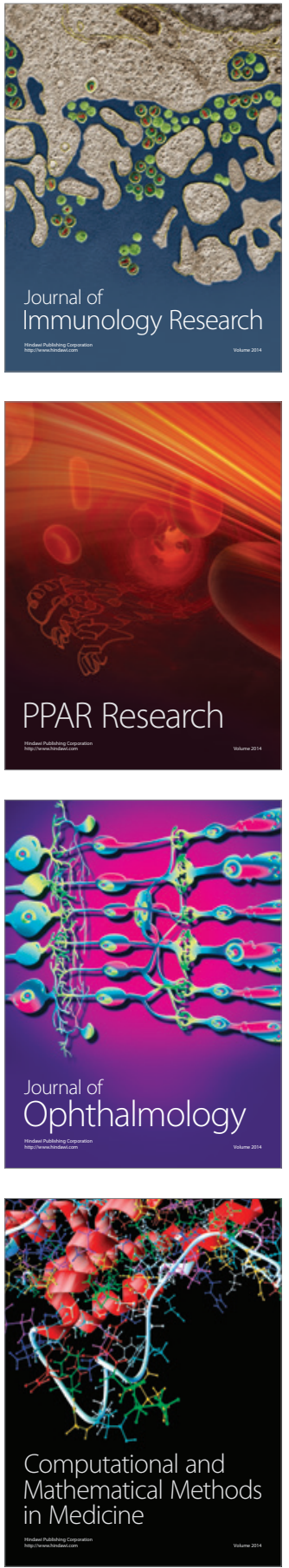

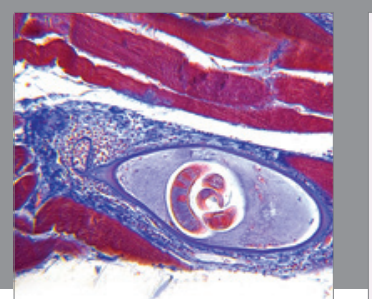

Gastroenterology Research and Practice

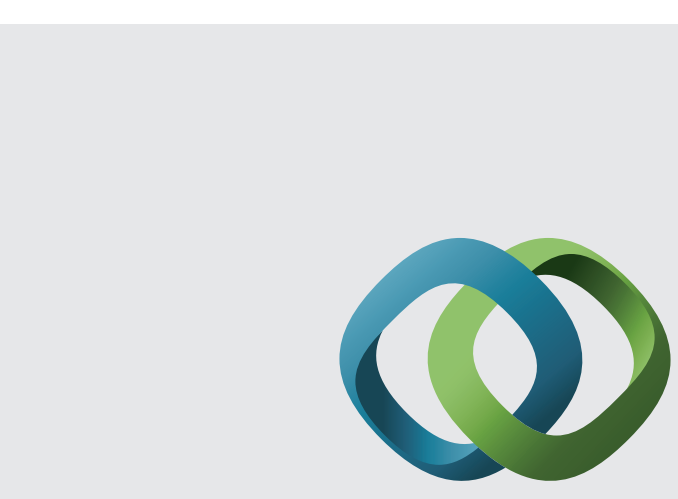

\section{Hindawi}

Submit your manuscripts at

http://www.hindawi.com
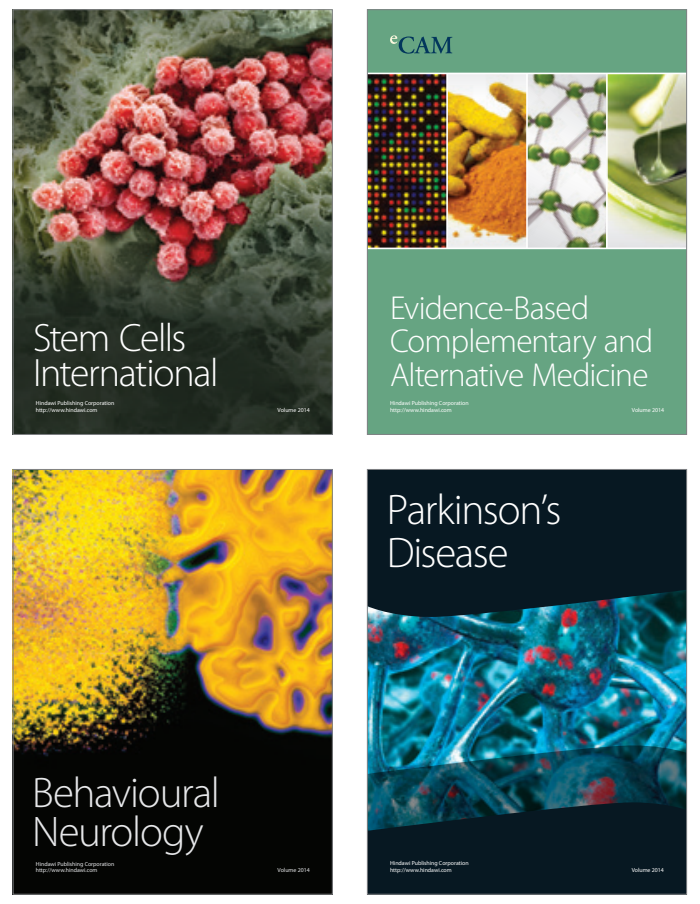
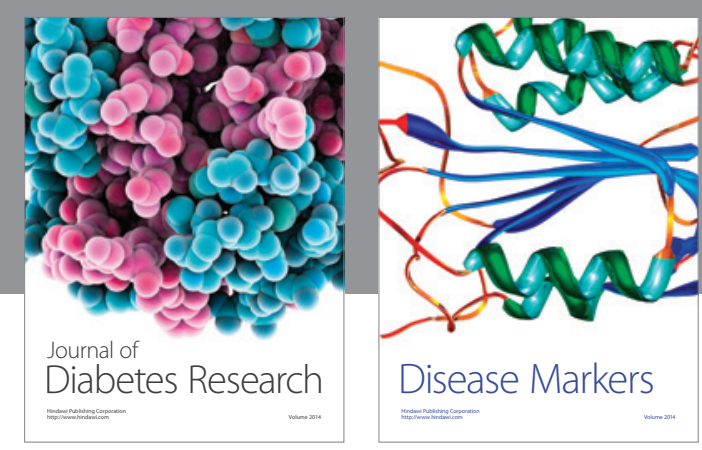

Disease Markers
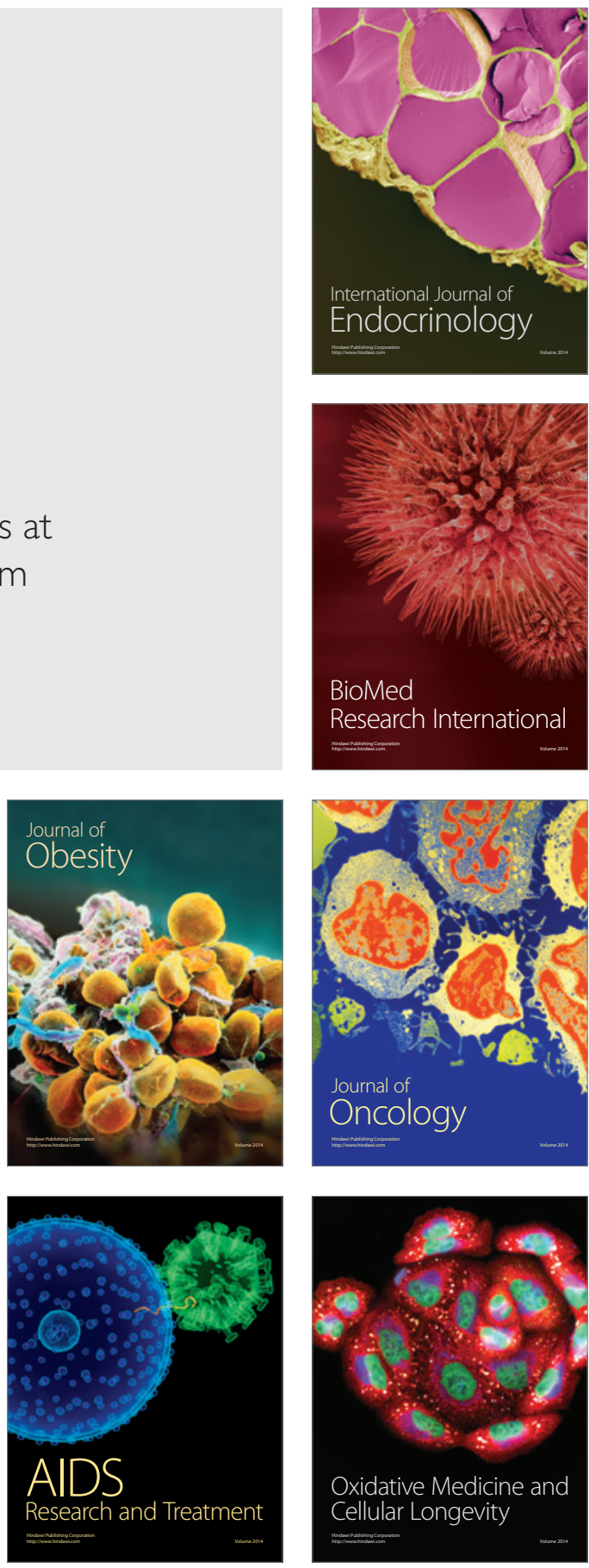